\title{
'Aid intervention' in the occupied Palestinian territory: do Gulf Arab donors act differently from Western donors?
}

DOI:

10.1080/14678802.2019.1608024

\section{Document Version}

Accepted author manuscript

Link to publication record in Manchester Research Explorer

\section{Citation for published version (APA):}

Turner, M. (2019). 'Aid intervention' in the occupied Palestinian territory: do Gulf Arab donors act differently from Western donors? Conflict, Security and Development, 19(3), 283-288.

https://doi.org/10.1080/14678802.2019.1608024

\section{Published in:}

Conflict, Security and Development

\section{Citing this paper}

Please note that where the full-text provided on Manchester Research Explorer is the Author Accepted Manuscript or Proof version this may differ from the final Published version. If citing, it is advised that you check and use the publisher's definitive version.

\section{General rights}

Copyright and moral rights for the publications made accessible in the Research Explorer are retained by the authors and/or other copyright owners and it is a condition of accessing publications that users recognise and abide by the legal requirements associated with these rights.

\section{Takedown policy}

If you believe that this document breaches copyright please refer to the University of Manchester's Takedown Procedures [http://man.ac.uk/04Y6Bo] or contact uml.scholarlycommunications@manchester.ac.uk providing relevant details, so we can investigate your claim.

\section{OPEN ACCESS}




\section{'Aid Intervention' in the Occupied Palestinian Territory: Do Gulf Arab Donors Act Differently from Western donors?}

\section{Mandy Turner}

$[2,800$ words $]$

\section{Abstract:}

This contribution uses an expanded conceptualisation of intervention based on the understanding of it as an attempt to influence, negatively or positively, the political context/direction of a country/situation. It does this through the concept of 'aid intervention' in the conflictcontext of Israel and the occupied Palestinian territory (OPT). Based on over 12 years of research experience of aid donors in this context, this contribution compares the stated principles, as well as the methods and practices, of the main western (US and EU) and nonwestern states (the Gulf Arab States) involved in providing aid. It is argued that while there are some interesting differences, there are some striking similarities, thus offering a critique and corrective to the prejudices that underpin the distinctions of 'western' and 'nonwestern', 'liberal' and 'illiberal'.

This contribution uses an expanded conceptualisation of intervention, understanding it as constituting an attempt to influence the political context/direction of a country/situation. It uses the concept of 'aid intervention' in the conflict-context of Israel and the occupied Palestinian territory (OPT) because it is generally recognised that without aid the developmental and governance framework introduced after 1993 would have long ago collapsed. Furthermore, both western and Arab donors provide substantial amounts of aid to the OPT - and have done so for many decades. This, therefore, makes it a good case to explore potential differences and similarities in terms of the stated and unstated motives, programming and policies, and modalities of operation of the main western (US and EU) and non-western (Gulf Arab) states involved in providing aid.

There are, of course, differences within these two sets of actors, and some changes in practices across historical periods. However, sufficient similarities in motives and operational practices make them a relatively coherent separate set of actors, and this allows us to critically unpack some of the distinctions that this forum seeks to explore, i.e. between 'western' and 'non-western', 'liberal' and 'illiberal'; here the terms and distinction used are 'western' and 'Arab'. This short commentary will first outline the problems with statistics for Arab aid, then move on to a comparison of beliefs and motivations, as well as programming and operational modalities; it concludes with comments on the similarities and differences between the two.

\section{Lies, damn lies, and aid statistics}

It is perhaps unfair to refer to aid statistics as "lies" as, in many ways, their incompleteness is not intentional but rather a result of the varying definitions of "aid". Nevertheless, it is notoriously difficult to get accurate figures for Arab aid, particularly given that there are multiple actors involved (i.e. private individuals, bilateral, and multilateral regional 
institutions including financial ones - although this is no different to western donors); the fact that major shares of their foreign aid is channelled through their Ministries of Finance and does not qualify as ODA; and that there appears to be a lot of unreported transfers. ${ }^{1}$ Moreover, although pledges are more generous than disbursements for all donors, this is particularly pronounced amongst Arab ones. Arab aid statistics, however, are becoming increasingly more accurate because of better tracking and reporting by governments and multilateral inter-Arab agencies (including the Arab Coordination Group, which has had regular meetings with OECD DAC since 2009). ${ }^{2}$ However, western aid statistics are also not entirely transparent, especially to the OPT, as indicated by the fact that OECD DAC figures are never accurate. ${ }^{3}$

The four biggest Arab donors are Saudi Arabia, the United Arab Emirates, Qatar, and Kuwait (combined they provide around 90 per cent of all Arab aid financing and are the main donors to the $\mathrm{OPT}^{4}$ ). Saudi Arabia is one of the biggest donors in general to the OPT, while Qatar is the biggest donor to Gaza - this is reflective (and constitutive) of the rivalry between these two Gulf states vis-à-vis competition for regional influence and support for allies, which has grown in recent years and has, since 2017, burst into outright confrontation. ${ }^{5}$ Furthermore, Arab donors, particularly Saudi Arabia, have been criticised for "exporting" Islamist extremism, and the negative publicity and rebukes from western states over this has provoked more Arab state oversight of aid and private charitable funds. So while Arab states still tend to work a lot with religious groups, they do not impose certain religious values through aid-giving. ${ }^{6}$

\section{Motives: Zaqat, solidarity, and good old-fashioned political machinations}

Providing zaqat (Islamic charity) and solidarity with Palestinians is the stated motive of Arab donors to the OPT; all Arab states perceive the situation as unjust, and many have also given funds to 'frontline' states, i.e. those that border Israel. ${ }^{7}$ In addition to these stated motives, however, are a number of unstated ones (which can be gleaned from observing their actions), i.e. the promotion of diplomatic objectives and regional stability, and supporting allies. In many ways, therefore, the stated and unstated objectives for aid are not that dissimilar to some western states, particularly since the 2002 Arab Peace Initiative that supports the creation of a Palestinian state on the lands occupied in 1967 in exchange for full diplomatic and economic relations between Israel and the Arab world, thus reversing the Arab League's previous position known as “The Three No's", i.e. no peace deals, no diplomatic recognitions, and no negotiations. ${ }^{8}$ Until recently, Arab aid rarely went to states that held diplomatic relations with Israel, but this has, of course, changed since the signing of the Declaration of Principles in 1993, which led to a loosening of the Arab boycott and the opening of trade offices with Israel across the Arab world. ${ }^{9}$

When the motives of Arab donors are compared to those of western donors, the story is mixed. It is clear that US aid to the OPT has no solidarity aspect to it - or rather the solidarity is towards Israel which is regarded as a strategic ally. In all US Congressional reports on US aid to the OPT, it is stated that aid is intended to promote three US priorities: the first is to prevent attacks on Israel, the second is to foster "stability, prosperity, and selfgovernance that may incline Palestinians towards peaceful coexistence with Israel and a 'two-state solution'", and the third is humanitarian. ${ }^{10}$ Solidarity motives are given by some (mostly smaller) western donors - not from their stated policies and annual reports that tend to stick to the usual western aid buzzwords (e.g. promoting human rights, private sector development, civil society enhancement, women's empowerment; and supporting the twostate solution), but a sizeable proportion of western aid officials I have interviewed over the 
past 12 years believe that Palestinians should be supported to survive the occupation until it is ended via a political settlement. The difference between this and the Arab position is that most western donors also put Israel's interests and security at the forefront of their foreign policies, which translates into preferential trade and scientific links, diplomatic support (for some), and even on occasions 'solidarity' with Israel. ${ }^{11}$ This is one of the main - and obvious - differences between western and Arab donors in the OPT; although of course in principle their strategies are similar, i.e. using aid to support allies and to promote stability. And while the Gulf Arab donor states still tend to hide any relations with Israel, these connections have become more pronounced in the past few years, particularly between Israel and Saudi Arabia because of a common hostility to Iran.

Remaining on the issue of assisting allies, while western donors are united in their support for the Ramallah-based Fateh-led Palestinian Authority under the leadership of Mahmoud Abbas and for the isolation of Hamas which is currently ruling over the Gaza Strip, Arab donors are divided on this - with Qatar regarded as being more supportive of Hamas, and the other three regarded as being more supportive of the Palestinian Authority. Western donors would therefore appear to follow a state and treaty-based understanding of global order, i.e. of working with the PLO, the organisation regarded by the UN and most states to be the sole and legitimate representative of the Palestinian people. However, their actions have also clashed with the notion of democratic elections which was purportedly a key part of western intervention strategy in the Arab world at the time, because in 2006 western donors, boycotted Hamas, the political party that won the election, and continued to support the PLO and particularly Fateh, the leading PLO faction. ${ }^{12}$ So, again, by supporting their preferred ally, western donors are similar to Arab donors, despite the rhetoric. and their policy proclamations on 'local ownership' in aid relations were revealed to be hollow.

The motives for giving aid to the OPT are therefore not hugely different between the two sets of donors. For Arab donors, the general ethos of aid is charitable, humanitarian, developmental, and politically motivated. This is largely the same for western donors.

\section{Programming and modalities: bricks and mortar versus governance, sovereignty versus monitoring}

Bigger differences between Gulf Arab and western donors appear when programming and modalities of operation are compared. In terms of programming, Arab donors tend to focus on infrastructure, education, health and sanitation. ${ }^{13}$ They prefer to disburse large sums of money to a smaller number of projects, and frequently offer in-kind assistance (e.g. donations of food, medicine, vehicles). They do not undertake the type of governance and social protection strategies so currently beloved by western donors, and they rarely impose outside technical assistance on aid recipients. The main focus is bilateral, state-to-state funding that supports sovereignty and it is for this reason that they are vehemently against conditionalities. ${ }^{14}$ This relates back to their principle of non-interference in recipient country policies and is the main reason for their modality of operation in the OPT, i.e. budget support to the PA and working through local partners (particularly the Red Crescent), as well as providing funds for UNRWA (the UN agency that supports Palestinian refugees).

However, having said that, around two-thirds of European Commission aid is for PA budget support through its Pegase system; ${ }^{15}$ furthermore, the World Bank trust fund also gathers funds from (mostly) western donors for budget support. ${ }^{16}$ So, again, the differences in operation are perhaps, at least in the OPT, relative rather than absolute. But this is likely due to the political objective of keeping the PA afloat for reasons of stability rather than a 
commitment to going through the recognised local sovereign - in this case a non-sovereign governing authority. Generally, though, western donors are more interested in moulding political systems through advocacy, training, and capacity building - according to the OECD, 'capacity building' accounts for 25 per cent of its members' aid. ${ }^{17}$ Arab donors have little interest in these areas; indeed they do not interfere in governance and rarely bring in their own experts - although this may be because it is difficult for Arab donors to bring in experts to the OPT, as they have to pass through Israeli-controlled borders (some Arab advisers, however, have been able to enter Gaza through its border with Egypt).

It is generally recognised that the practices of Arab donors are better with regards to local ownership than western donors because they use local implementing partners and do not create their own. The Arab Fund, for instance, supports a youth employment training programme, but it leaves the implementation to Palestinian organisations.

Arab donors tend to be criticised for not being overly concerned with monitoring and evaluation compared to western donors. However, they have their own methods that can actually be quite intrusive, i.e. sometimes they insist on being involved right from the planning stage; and because they have a lot of money, people put up with the interference. When it came to funding for Gaza reconstruction, for instance, the Kuwait Fund was heavily involved, and even had their own committee of engineers to look at the plans for implementation. ${ }^{18}$ Furthermore, while Arab donors use competitive bidding, they like to work with people and organisations with which they have built up trust, so while it takes a long time to build relations with Arab donors, it can reap substantial rewards. ${ }^{19}$

\section{Conclusion: procurement, plaques and prejudices}

In a few of the recent reports on Arab aid, 'recommendations' have been made that Arab donors should replicate western practices in terms of greater transparency, being more 'propoor' in their policies, have more stringent procurement practices, and institute better monitoring and evaluation to determine impact. ${ }^{20}$ However, this ignores the political and cultural beliefs and motivations that underpin the Arab model, i.e., that (after stringent procedures to get the funding) recipients are generally trusted to undertake the activities without too much interference. And despite criticisms to the contrary, Arab donors do measure impact and require reporting from recipients.

One striking difference between western and Arab donors is that the latter do not tend to follow developmental fads that underpin western aid strategies, and if they do it is generally limited and delayed. ${ }^{21}$ However, one striking similarity, at least in the OPT, is that both sets of donors like plaques everywhere announcing their charitable 'generosity' to the recipient population - and so at least on the issue of self-promotion they are in unison.

In terms of intervention studies, the main 'take home' from this analysis is that the huge claims made regarding differential aid intervention policies and practices need to be empirically unpacked rather than taken for granted, because there are striking similarities that hide behind the prejudices that underpin the distinctions of 'western' and 'non-western', 'liberal' and 'illiberal', particularly as they pertain to the example of the OPT.

\section{Acknowledgements}

I would like to thank Dana Erekat for comments made on an earlier draft. However, any errors and perspectives belong to me. I would also like to thank the Middle East Centre at the London School of Economics for the LSE Academic Collaboration with Arab Universities 
Grant MEC-AC-2015-03 'Advancing research and teaching in political economy in the oPt' which made this research possible.

\section{Bibliography}

Aid Management and Coordination Directorate, 2015. 'Donor Support Background, Ad Hoc Liaision Committee Meeting Sept 29-30, New York', Ramallah, State of Palestine.

Ahren, R. 2018. 'Solidarity with Israel Central to German Foreign Policy, New FM Says', The Times of Israel, 25 March. https://www.timesofisrael.com/solidarity-with-israelcentral-to-german-foreign-policy-new-fm-says/

Barakat, S. and Zyck, S.A., 2010. 'Gulf State Assistance to Conflict-Affected Environments', London: London School of Economics.

Buttu, D. 2019. 'The Oslo Agreements - What Happened?', in Turner, M. (ed.) 2019. From the River to the Sea: Palestine and Israel in the Shadow of 'Peace', Rowman and Littlefield, (forthcoming).

Guy, D. 2016. 'Aid Workers Talk Endlessly About Capacity Building, But What Does it Really Mean?', The Guardian, 10 November, https://www.theguardian.com/globaldevelopment-professionals-network/2016/nov/10/what-does-capacity-building-mean

Harmer, A., Martin, E. (eds.) 2010. 'Diversity in Donorship: Field Notes', London: Overseas Development Institute.

Nuemayer, E. 2004. 'Arab-Related Bilateral and Multilateral Sources of Development Finance: Issues, Trends and the Way Forward', The World Economy, 27(2).

Oxford Research Group. 2008. 'The Arab Peace Initiative: Why Now?, London: ORG.

Reed, J. 2017. 'Isolation of Gaza's Biggest Donor Rattles Hamas', Financial Times, 15 June, https://www.ft.com/content/581fbcec-51b8-11e7-bfb8-997009366969

Shushan, D. and Marcoux, C. 2010. 'Assessing Arab Aid: Trends, Explanations, and Unreported Transfers', AidData Conference, Oxford University, 22-25 March.

Turner, M. 2016. 'Peacebuilding as Counterinsurgency in the Occupied Palestinian Territory', Review of International Studies, 41(1).

Villanger, E. 2007. 'Arab Foreign Aid: Disbursement Patterns, Aid Policies and Motives', CMR Report 2. Bergen: CHR. Michelson Institute.

Zanotti, J. 2016. 'US Foreign Aid to the Palestinians', US Congressional Research Service, Washington DC, 16 December.

\section{Interviews with author}

Dana Erekat, former head of aid management, Ministry of Finance and Planning, State of Palestine, Ramallah, 21 March 2017.

Senior development official [anonymised], East Jerusalem, 16 March 2018.

\section{Endnotes}

${ }^{1}$ Barakat and Zyck. 'Gulf State Assistance', 3-6; Harmer and Martin (eds.), 'Diversity in Sponsorship', 2224.

2 DAC Working Group, 'Update on Reporting by Multilateral Organisations'.

${ }^{3}$ Interview with Palestinian Authority Ministry of Planning official, Ramallah, 21 March 2017.

${ }^{4}$ Barakat and Zyck, 'Gulf State Assistance', 3.

${ }^{5}$ Reed, 'Isolation of Gaza'. 
${ }^{6}$ Interview with senior development official, East Jerusalem, 16 March 2018.

7 Barakat and Zyck, 'Gulf State Assistance', p.13.

${ }^{8}$ Oxford Research Group, 'The Arab Peace Initiative'.

${ }^{9}$ Buttu. 'The Oslo Agreements - What Happened?'.

${ }^{10}$ Zanotti, 'US Foreign Aid to the Palestinians', 1. Although support for a 'two-state solution' only became official policy in 2002.

${ }^{11}$ Ahren, 'Solidarity with Israel Central to German Foreign Policy'.

${ }^{12}$ Turner, 'Peacebuilding as Counterinsurgency', 73-98

${ }^{13}$ Shushan and Marcoux, 2010, p.23.

${ }^{14}$ Villanger, 'Arab Foreign Aid', 14.

${ }^{15}$ Aid Management and Coordination Directorate, 'Donor Support Background'.

${ }^{16}$ Some Arab donors, such as Kuwait, also contribute to the World Bank trust fund.

${ }^{17}$ Guy, 'Aid Workers Talk Endlessly About Capacity Building'.

${ }^{18}$ Interview with Dana Erekat, former head of aid management, Ministry of Finance and Planning, State of Palestine, Ramallah, 21 March 2017.

${ }_{19}$ Interview with former senior development official, East Jerusalem, 16 March 2018.

${ }^{20}$ Nuemayer, 'Arab-Related Sources of Development Finance', 281-300; Villanger, 'Arab Foreign Aid',

${ }^{21}$ Neumayer, 'Arab-Related Sources of Development Finance', 14. 